\begin{tabular}{|c|c|c|c|c|c|}
\hline JRL & Vol.13 & No.1 & Hal. 71 - 84 & $\begin{array}{c}\text { Jakarta, Juni } \\
2020\end{array}$ & $\begin{array}{c}\text { p-ISSN : 2085.38616 } \\
\text { e-ISSN : 2580-0442 }\end{array}$ \\
\hline
\end{tabular}

\title{
APLIKASI TEKNOLOGI PENGOLAHAN AIR ASIN MENGGUNAKAN MEMBRAN REVERSE OSMOSIS DI PULAU BARRANG CADDI, MAKASSAR
}

\author{
Oman Sulaeman, Citra Ardiana \\ Pusat Teknologi Lingkungan, BPPT oman.sulaeman@bppt.go.id; \\ citra.ardiana@bppt.go.id
}

\begin{abstract}
Abstrak
Pulau Barrang Caddi memiliki luas wilayah 4 ha dengan jarak $11 \mathrm{~km}$ dari Kota Makassar dan merupakan pulau yang padat penduduknya yang berjumlah 1263 jiwa. Untuk mendapatkan air bersih, masyarakat umumnya menggali sumur dangkal, namun airnya berubah menjadi asin pada musim kemarau Pada pemukiman yang padat, kualitas air sumurnya menurun dari tahun ke tahun. Air bersih merupakan barang langka di pulaupulau kecil, terutama pada lokasi yang penduduknya padat. Kualitas air tanah dangkal semakin menurun disebabkan oleh intrusi air laut, dimana air menjadi asin karena tingginya kadar garam. Untuk menyajikan air minum yang sehat harus dibeli dengan harga yang mahal dan hanya ada di Kota Makassar. Untuk mengatasi masalah tersebut maka diperlukan pengolahan air dengan teknologi reverse osmosis yang dapat mengolah air asin menjadi air tawar. Kegiatan ini meliputi survei, desain, pretreatment, pengolahan lanjut dan pasca produksi. Teknologi Sea Water Reverse Osmosis (SWRO) pada Unit Arsinum yang diaplikasikan di P. Barrang Caddi ini menghasilkan air produk olahan yang layak minum dan sesuai dengan baku mutu. Selain itu, dilakukan pula perhitungan biaya energi hasil Unit Arsinum tersebut untuk memenuhi biaya operator dan perawatan.
\end{abstract}

Kata Kunci: teknologi, pengolahan, air asin, reverse osmosis, air minum 


\title{
APPLICATION OF SALT WATER TECHNOLOGY USING REVERSE OSMOSIS MEMBRANE IN BARRANG CADDI ISLAND, MAKASSAR
}

\begin{abstract}
Barrang Caddi Island has an area of 4 ha with a distance of $11 \mathrm{~km}$ from Makassar City and is a densely populated island with a total of 1263 inhabitants. To get drinking water, the community generally digs shallow wells, but the water change salty in the dry season. In dense settlement, the quality of the well decreases from year to year. Dringking water is a rare commodity on small island, especially in densely populated location. The quality of shallow ground water is decreasing due to sea water intrusion, where water becomes salty due to high levels of salt. To provide healthy drinking water must be purchased at an expensive price and only obtain in Makassar City. To overcome this problem, water treatment with reverse osmosis technology is needed that can process salt water into fresh water. These activities include surveying, design, pretreatment, advanced processing and post-production. Sea Water Reverse Osmosis (SWRO) technology in the Arsinum Unit which is applied in P. Barrang Caddi produces treatment water that is suitable for drinking and complies with quality standards. In addition, the calculation of the Arsinum Unit's energy costs is also calculated to meet the operator and maintenance costs.
\end{abstract}

Keywords: technology, processing, salt water, reverse osmosis, drinking water 


\section{PENDAHULUAN}

Pulau Barrang Caddi terletak di sebelah timur Pulau Barrang Lompo yang berbentuk memanjang timur laut - barat daya, dengan luas 4 ha. Pulai ini berjarak $11 \mathrm{~km}$ dari Makassar dan termasuk ke dalam pulau yang padat penduduknya dengan jumlah 1263 jiwa. Mayoritas penduduknya bekerja sebagai nelayan tradisional, sehingga ketersediaan sarana air bersih juga merupakan salah satu faktor yang sangat penting di pulau ini (Safri, 2006).

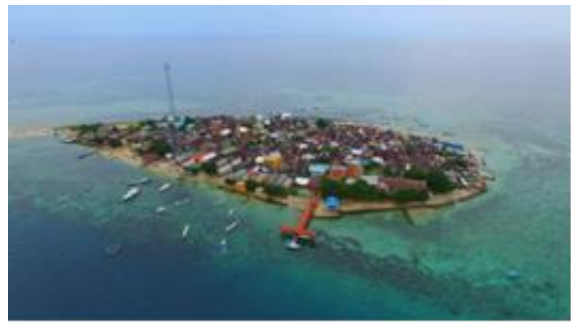

Gambar 1. Pulau Barang Caddi

Air bersih merupakan barang langka di pulau-pulau kecil, terutama yang penduduknya cukup rapat. Untuk mendapatkan air bersih masyarakat umumnya menggali sumur dangkal, namun pada musim kemarau berubah menjadi asin dan pada pemukiman yang padat kualitasnya menurun dari tahun ke tahun (Herlambang, 2016).

Kualitas air tanah dangkal semakin menurun disebabkan oleh intrusi air laut, dimana air menjadi asin karena tingginya kadar garam dan untuk menyajikan air minum yang sehat harus dibeli dengan harga yang mahal dan hanya diperoleh dari Kota Makassar. Sumber air utama penduduk Pulau Barrang Caddi pada waktu musim penghujan adalah menampung air hujan dan pada waktu musim kemarau kebutuhan air dipenuhi dari daerah lain yang diangkut dengan kapal-kapal nelayan. Dalam kondisi semacam ini sangat diperlukan instalasi pengolahan air yang mampu mengolah air asin menjadi air tawar dan siap minum.

Salah satu cara yang memungkinkan untuk pemenuhan air bersih, khususnya air minum adalah dengan pembangunan unit Instalasi Pengolahan Air yang sesuai dengan kondisi air baku. Berdasarkan data kualitas air baku, proses yang harus diterapkan meliputi oksidasi, filtrasi dan desalinasi air asin dengan sistem Reverse osmosis (Osmosa Balik) (William, 2003). Sumber air yang secara kuantitas tidak terbatas adalah air laut. Akan tetapi air laut mengandung kadar garam dan TDS (Total Dissolved Solid) yang sangat tinggi sehingga diperlukan pengolahan lebih lanjut agar dapat dimanfaatkan sebagai air minum (Widayat, 2007).

Peningkatan kebutuhan air bersih menjadikan air laut layak digunakan sebagai sumber alternatif. Konsentrasi salinitas (Total Dissolved Solid, TDS) yang tinggi memerlukan teknologi pengolahan yang mampu memisahkan bahan-bahan terlarut. Teknologi desalinasi menggunakan membran Reverse osmosis (RO) mampu memisahkan kontaminan di dalam air laut seperti partikel padat, kekeruhan, cyst, bakteri, virus, warna, 
senyawa organik dan padatan terlarut (Widiasa dan Susanto, 2016).

Tujuan dari kegiatan ini adalah mengatasi masalah pemenuhan air siap minum di Pulau Barrang Caddi dengan penerapan teknologi reserves osmosis didasarkan pada keberadaan dan kondisi air baku, baik dari sisi kualitas dan kuantitas air baku yang ada di lokasi terpasang dan mengatasi

Kegiatan ini meliputi survei dan penetapan lokasi , desain pengolahan air asin didasarkan pada kualitas air baku yang akan diolah yang terdiri atas desain pretreatment air baku dan desain pengolahan lanjut lanjut dan pasca produksi. Teknologi Sea Water Reverse Osmosis (SWRO) pada Unit Arsinum yang diaplikasikan di

P. Barrang, Makasar ini menghasilkan air produk olahan yang dianalisa di Laboratorium PTL, BPPT. Hasil air olahan diharapkan dapat memenuhi baku mutu air yang layak minum sesuai dengan standar yang berlaku. Selain itu, dilakukan pula perhitungan penjualan air olahan yang hasilnya dapat digunakan untuk memenuhi biaya energi, biaya operator dan biaya perawatan. Dengan aplikasi unit Arsinum diharapkan kebutuhan air dapat dipenuhi dan sesuai dengan kemampuan ekonomi masyarakat di P.Barrang Caddi tersebut.

\section{METODE}

Metode yang digunakan pada penerapan unit pengolah air siap minum di Pulau Barrang Caddi ini adalah sebagai berikut.

1. Survey Lokasi

Survey lokasi dilakukan untuk mengetahui kualitas air baku, jumlah penduduk yang akan dilayani, kondisi sosial \& ekonomi masyarakatnya.

2 Sampling Air Baku

Pengambilan sampel dan analisa air baku dilakukan pada beberapa titik untuk mendapatkan data kualitas air dari hasil sampling, sehingga diketahui kadar TDS yang terdapat dalam air sampel adalah $12.930 \mathrm{mg} / \mathrm{L}$.

3. Penentuan Lokasi

Penentuan lokasi ini dilakukan dengan pertimbangan segi teknis pembangunan, pengoperasian dan distribusi. Instalasi Pengolahan Air (IPA) ditempatkan pada jarak terdekat dengan pemukiman dan sumber air yang akan diolah.

4. Desain

Data kualitas air baku digunakan untuk menentukan desain proses yang akan digunakan, yaitu sebagai acuan penentuan jumlah bahan-bahan kimia, sistem pengolahan pendahuluan yang akan digunakan dan sistem pengolahan lanjutan untuk air asin.

5. Aplikasi

Aplikasi pengolahan air asin menjadi air tawar siap minum diawali dengan pembangunan bangunan pelindung peralatan, kemudian installing pembangkit listrik dan konstruksi unit proses dalam Sistem IPA. 
6. Pelatihan

Pelatihan sumberdaya manusia masyarakat setempat juga harus mampu mengelola Instalasi Pengolahan Air tersebut, yaitu mengoperasikan dan mensosialisasikan hasil pengelolaan IPA.

\section{PEMBAHASAN}

\subsection{Survei dan Penetapan Lokasi}

Survei ini dilaksanakan untuk mendapatkan bahan atau materi antara lain survei sampel air, mulai dari pengambilan sampel untuk diketahui kualitas air baku, kuantitas air baku berdasarkan pada sumber, baik itu dari air tanahatau permukaan termasuk potensinya. Survei sumberdaya yang ada listrik PLN atau generator atau diesel yang harus dipersiapkan sendiri.

Selain itu juga dilakukan survei pasar atau pengguna, kesiapan tempat, sumberdaya manusia dan aksesibilitas terhadap operator atau home service, bengkel dan supplier peralatan bila terjadi kerusakan.

Tabel 1. Hasil Analisa Air Baku

\begin{tabular}{|c|c|c|c|}
\hline No & Parameter & Satuan & Hasil Air Baku \\
\hline 1 & $\mathrm{pH}$ & - & 4,1 \\
\hline 2 & Kekeruhan & $\mathrm{NTU}$ & 242 \\
\hline 3 & TDS & $\mathrm{mg} / \mathrm{L}$ & 12.93 \\
\hline 4 & Temperatur & ${ }^{\circ} \mathrm{C}$ & 26 \\
\hline 5 & Besi (Fe)Terlarut & $\mathrm{mg} / \mathrm{L}$ & 388 \\
\hline 6 & Mangan (Mn)Terlarut & $\mathrm{mg} / \mathrm{L}$ & 6 \\
\hline
\end{tabular}

Sumber: Hasil Analisa Laboratorium PTL, 16 Desember 2019

Dari hasil sampling air baku tersebut diketahui bahwa kadar TDS yang terkandung dalam air sampel adalah $12.93 \mathrm{mg} / \mathrm{L}$.

\subsection{Desain}

Desain pengolahan air asin didasarkan pada kualitas air baku yang akan diolah dan dibutuhkan proses pretreatment filtrasi dengan alur pengolahannya sebagai berikut. Air baku dipompa ke tangki penampung air baku, kemudian dari tangki air baku, air disaring oleh saringan pasir sekaligus diinjeksi dengan larutan kaporit dengan menggunakan pompa kimia, agar zat besi atau mangan yang larut dalam air baku dapat dioksidasi menjadi bentuk senyawa oksida Besi

(Fe) atau Mangan (Mn) yang tak larut dalam air sehingga dapat disaring pada saringan pasir.

Selain itu, pemberian kaporit berfungsi untuk membunuh mikroorganisme dan bakteri yang 
terdapat pada air baku, yang dapat menyebabkan

biofouling

(penyumbatan oleh mikroba) di membran juga sebagai bahan aktivasi media manganese zeolit. Air yang telah dioksidasi kaporit dan juga padatan tersuspensi (SS) yang berupa partikel halus, plankton dan lainnya selanjutnya dapat disaring pada saringan pasir cepat (sand filter). Air yang keluar dari saringan pasir selanjutnya dialirkan ke filter Untuk menghilangkan bau atau warna serta polutan mikro. Karbon aktif ini mempunyai fungsi untuk menghilangkan senyawa warna dan bau pada air baku, kemudian air ditampung pada tangki air olahan. Air ini diolah kembali pada unit reverse osmosis sehingga air tersebut dapat layak dikonsumsi sebagai air minum dan ditampung pada tangki air minum.

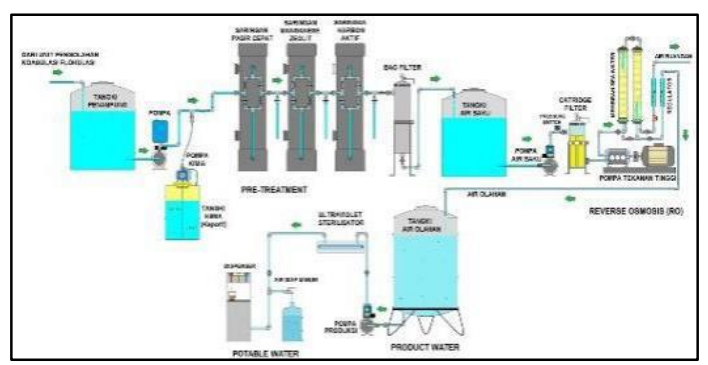

Gambar 2. Flow Chart Unit Reverse Osmosis dan Unit Pasca Produksi

\subsection{Desain Pretreatment Air Baku}

Dalam pengolahan air yang menggunakan sistem membran reverse osmosis dibutuhkan standar air baku yang sangat ketat, artinya air yang masuk ke dalam unit elemen membran reverse osmosis harus mempunyai kualitas yang sesuai
Mangan Zeolit (manganese greensand filter) dan karbon aktif (activated carbon filter). Dengan adanya filter Mangan Zeolit ini, zat besi atau mangan yang belum teroksidasi dapat dihilangkan sampai konsentrasi $<0.1 \mathrm{mg} / \mathrm{l}$. Zat Besi dan Mangan ini harus dihilangkan terlebih dahulu karena zat-zat tesebut dapat menimbulkan kerak (scale) pada kulit membran.

dengan standar desain elemen membran tersebut.

Unit ini berfungsi untuk menyaring partikel kasar yang berasal dari air baku dan hasil oksidasi kalium permanganat atau klorin, termasuk besi dan mangan. Unit filter berbentuk silinder dan terbuat dari bahan PVC. Unit ini dilengkapi dengan kran - kran yang berfungsi sebagai pengatur arah aliran, filtrasi atau backwash sehingga untuk proses pencucian balik dapat dilakukan dengan sangat sederhana, yaitu dengan hanya memutar kran tersebut sesuai dengan petunjuknya.

Dengan dilengkapi oleh dua buah water moore, maka penggantian media filter dapat dilakukan dengan mudah. Selanjutnya Gambar 3 menjelaskan bentuk dan ukuran filter multimedia dan pada Tabel 2 dapat dilihat kebutuhan peralatan dan bahannya. 


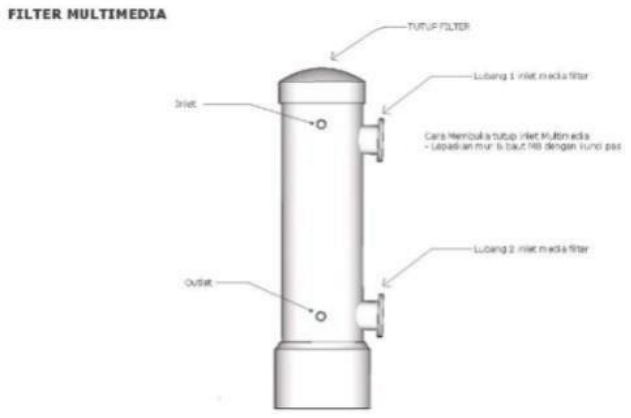

Gambar 3. Filter Penyaring

Multimedia

Tabel 2. Spesifikasi Filter

\begin{tabular}{|l|l|}
\hline Tipe & Tubular 12" \\
\hline Tinggi & $120 \mathrm{~cm}$ \\
\hline Material & PVC \\
\hline Kapasitas & $1,4-1,8$ m3/jam \\
\hline Media & $\begin{array}{l}\text { Kerikil 2 sak, Pasir } \\
\text { Silika, Manganese } \\
\text { Greensand, Karbon } \\
\text { Aktif }\end{array}$ \\
\hline Inlet, outlet & Pipa 1" \\
\hline
\end{tabular}

\subsection{Desain Pengolahan Lanjut}

Pada bagian ini air yang sudah diolah pada penyaringan pendahuluan ditingkatkan kualitasnya. Pada fase ini penyaringan bukan lagi konvensional tetapi sudah ke penyaringan skala molekuler dengan menggunakan membran semipermeable atau yang disebut reverse osmosis selanjutnya disingkat RO. Unit ini mempunyai bagian - bagian penting untuk

menunjang kinerja unit secara kesatuan ketika melakukan penyaringan, beberapa perangkat diantaranya adalah sebagai berikut.

\section{Cartridge Filter}

Cartidge filter berfungsi sebagai penyaring partikel atau material halus yang lolos dari pengolah pendahuluan yang mempunyai ukuran lebih kecil dari 100 mikron. Casing filter ini terbuat dari stainless steel anti karat, berisi 3 buah media cartridge dengan ukuran pori-pori 10 mikron.

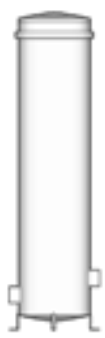

Gambar 4. Cartridge Filter

Tabel 3. Spesifikasi Cartridge

\begin{tabular}{|c|l|l|}
\hline No. & Peralatan Microfilter & \multicolumn{1}{|c|}{ Keterangan } \\
\hline & BN 2 & \\
1. & Material Casing Isi & SS 304 \\
2. & Cartridge & $3 \times 20$ Inci (D 2") \\
3. & Inlet Outlet & $1 \frac{1}{2}$ Inci \\
\hline
\end{tabular}

\section{Pressure Switch}

Peralatan ini berfungsi mematikan sistem apabila tejadi tekanan melebihi kemampuan operasional vessel membrane terutama mematikan pompa tekanan tinggi. 


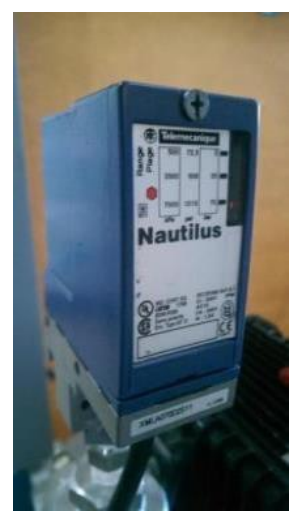

Gambar 5. Pressure Switch

Tabel 4. Spesifikasi Pressure Switch

\begin{tabular}{|c|l|l|}
\hline No. & $\begin{array}{l}\text { Peralatan } \\
\text { Pressure Switch }\end{array}$ & Keterangan \\
\hline 1. & Telemecanique & SS 316 \\
2. & Nautilus Range & $5-70 \mathrm{bar}$ \\
3. & Voltase Inlet & $220-240 \mathrm{~V}$ \\
4. & Outlet & $1 / 4$ Inci \\
& & \\
\hline
\end{tabular}

3. Pompa Tekanan Tinggi

Pompa tekanan tinggi digunakan untuk mengalirkan air dari sistem pengolahan pendahuluan ke sistem penyaringan membran RO. Untuk menembus membran osmosa balik membutuhkan tekanan besar. Air baku air tawar dalam hal ini air sungai tekanan yang dibutuhkan berkisar $40-55 \mathrm{~kg} / \mathrm{cm}^{2}$. Tegangan listrik yang dibutuhkan oleh pompa ini adalah 380 Volt (3 phasa). Pompa ini bertipe plunger dengan tekanan input minimal $2 \mathrm{~kg} / \mathrm{cm}^{2}$ untuk memastikan pompa tekanan tinggi ini mendapat pasokan air dari unit pretreament, maka dipasang safety pressure atau pengaman tekanan pompa pada pipa inlet. Alat ini akan bekerja memutus aliran listrik apabila pompa tidak mendapat pasokan air sebesar 2 $\mathrm{kg} / \mathrm{cm}^{2}$ dari pompa umpan.

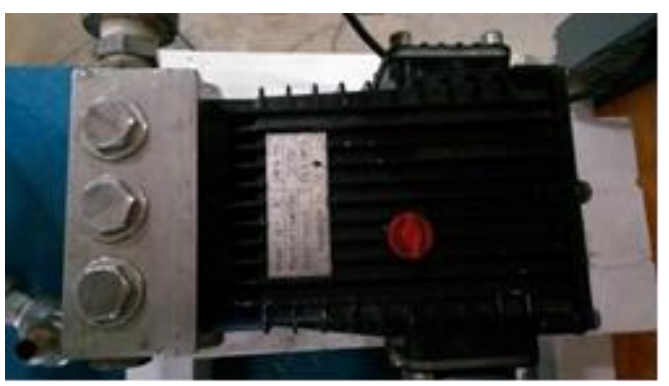

Gambar 6. Pompa Tekanan Tinggi

4. Membran

Membran osmosa balik merupakan peralatan utama dari sistem pengolahan air secara keseluruhan. Unit ini terdiri dari selaput membran yang digulung secara spiral dengan pelindung kerangka luar (vessel) yang tahan terhadap tekanan tinggi. Daya tahan membran ini sangat tergantung pada proses pengolahan awal, tahan lama.

Pada unit ini proses penyaringan tidak konvensional seperti pada penyaringan pendahuluan, tetapi penyaringan skala molekuler. Dimana hanya molekul air $\mathrm{H}_{2} \mathrm{O}$ yang dapat menembus membran semipermeable, sedangkan pengotor - pengotornya terbuang bersama aliran reject atau aliran buangan. 


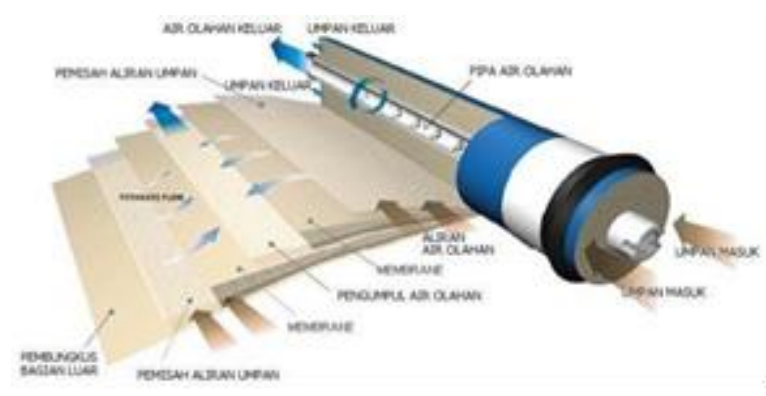

Gambar 7. Membran Reverse Osmosis

Tabel 5. Spesifikasi Membran

Reverse osmosis

\begin{tabular}{|l|l|l|}
\hline No. & Peralatan membran & Keterangan \\
\hline & CSM & \\
1. & Tipe & RE $4040 \mathrm{SHN}$ \\
2. & Kapasitas & $4,5 \mathrm{~m}^{3} / \mathrm{hr}$ \\
3. & Tekanan maximum CIP & $8,27 \mathrm{MPa}$ \\
4. & pH range & $1.0-13.0$ \\
5. & Area membrane & $6,9 \mathrm{~m}^{2}$ \\
& Jumlah & 2 buah \\
\hline
\end{tabular}

Kapasitas $=$ kapasitas membran $\times$ jumlah membran

Kapasitas $=4.5 \frac{m^{d}}{h r} \times 2 b h=9 \frac{m^{d}}{h r}$

5. Pengatur Tekanan

Fungsi dari perangkat ini adalah mengatur tekanan operasi pada membran osmosa balik sehingga perbedaan kesetimbangan antara air baku dan air olahan dapat tercapai. Akibat dari perbedaan kesetimbangan tersebut maka air baku dengan konsentrasi padatan terlarut yang tinggi menembus membran menjadi air hasil olahan. Sedangkan konsentrasi padatan terlarutnya tidak dapat menembus membran sehingga air buangan atau air reject menjadi dua kali lebih tinggi konsentrasi padatan terlarutnya ketimbang air baku yang diolah.

Kemampuan membran ini dalam melakukan penurunan konsentrasi padatan terlarut pada air baku umumnya sebanyak $90 \%$.

Air hasil olahan dengan konsentrasi rendah mengalir melalui flowmeter sehingga dapat diketahui debit hasil air olah, sedangkan air reject- nya juga melaui flowmeter reject. Perbandingan antara debit air buangan dan air olahan tidak boleh melebihi dari $50 \%$ dari total air yang diolah karena akan menyebabkan usia membran menjadi lebih pendek.

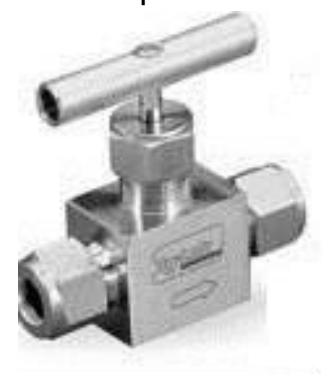

Gambar 8. Pengatur Tekanan

Tabel 6. Spesifikasi Kran Pengatur

Tekanan

\begin{tabular}{|r|l|l|}
\hline No. & $\begin{array}{c}\text { Peralatan pengatur } \\
\text { tekanan }\end{array}$ & \multicolumn{1}{|c|}{ Keterangan } \\
\hline 1. & Hypro Tipe & NV 4 F - 8 N - R \\
2. & In - Out & needle valve \\
3. & Tekanan & $1 / 2$ Inci SS 316 \\
& maximum & 6000 Psi \\
\hline
\end{tabular}

6. Aksesoris

Aksesoris merupakan

perlengkapan penunjang operasi 
yang cukup penting pada unit osmosa balik ini, aseoris ini meliputi petunjuk tekanan air baku dan tekanan operasi, alat ukur total padatan terlarut TDS (Total Dissolved Solid), serta panel kontrol untuk mengoperasikan unit secara keseluruhan.

\section{Skeed Unit Reverse Osmosis} Skeed Unit reverse osmosis digunakan sebagai pelindung peralatan yang menjadi satu kesatuan sistem reverse osmosis, perancangan skeed berdasarkan jumlah membran yang digunakan, jumlah pompa, kotrol panel unit ultrafiltrasi dan peralatan pendukung lainnya. Direncanakan skeed unit sebagai berikut.

$\begin{array}{ll}\text { Bahan rangka } & \text { : SS hollow 30×30 } \\ \text { Panjang } & : 60 \mathrm{~cm} \\ \text { Lebar } & : 50 \mathrm{~cm} \\ \text { Tinggi } & : 160 \mathrm{~cm}\end{array}$
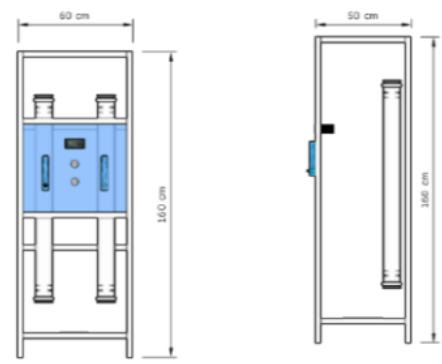

Gambar 9. Desain Rangka SWRO

\subsection{Pasca Produksi}

Air hasil pengolahan sistem osmosa balik ini ditampung pada tangki penampung, tangki ini terbuat dari stainless steel dengan kapasitas $1.2 \quad \mathrm{~m}^{3}$. Setelah ditampung maka air ini akan didistribusikan untuk proses produksi. Untuk menjaga agar air siap minum tersebut tidak terkontaminasi mikroba akibat kontak dengan udara luar makasebelum didistribusikan, air olahan tersebut diserilkan melalui unit ultraviolet sterillizator dan Unit Pasca Produksi.

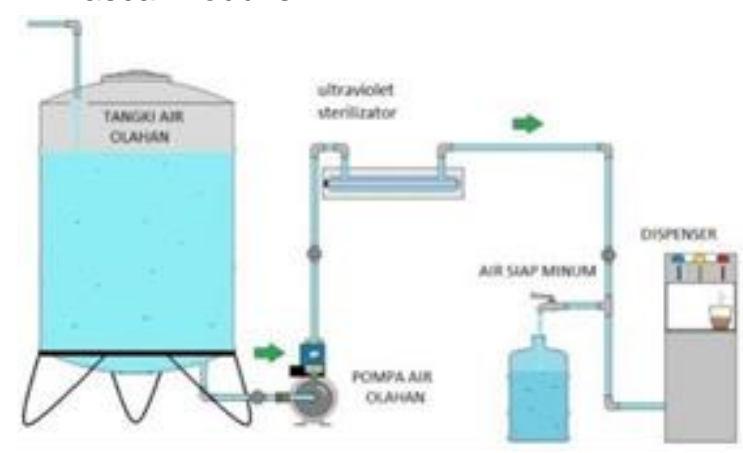

Gambar 10. Flowchart Unit Reverse Osmosis

\subsection{Aplikasi}

Lokasi pemasangan unit Arsinum ini dilakukan di Kantor Desa Pulau Barrang Caddi, Makassar. Penentuan titik lokasi () tersebut merupakan hasil diskusi dan musyawarah antara tim Teknis PTL, Badan Pengkajian dan Penerapan Teknologi. Dengan adanya fasilitas pemenuhan kebutuhan air minum di lokasi, maka diperkirakan sampah plastik (botol/gelas kemasan air mineral) juga akan berkurang. 
Sumber air baku untuk unit IPA Siap Minum ini adalah air laut. Walaupun sebenarnyakualitas air produksi PDAM sudah memenuhi baku mutu untuk air minum, namun sering kali suplainya tidak kontinyu dan juga sesekali kualitasnya menurun drastis karena adanya tingkat kekeruhan yang sangat tinggi, terutama bila terjadi hujan dengan curahan yang sangat tinggi. Sebagai konsekuensinya, maka pihak pengelola instalasi pengolahan air siap minum (IPA Siap Minum) tersebut, yaitu pihak Desa Pulau Barrang Caddi, Makassar harus pula melaksanakan kewajibannya dalam monitoring pengoperasian dan pemeliharaan IPA Siap Minum tersebut.

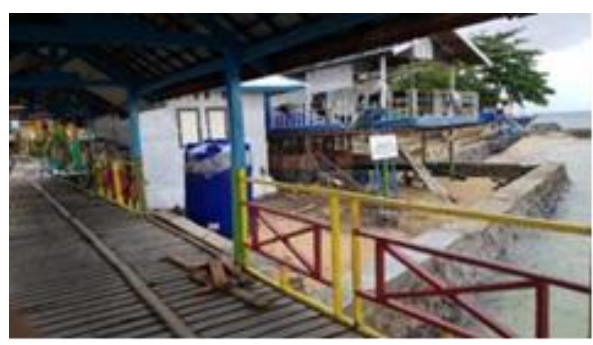

Gambar 11. Lokasi Bangunan Pelindung

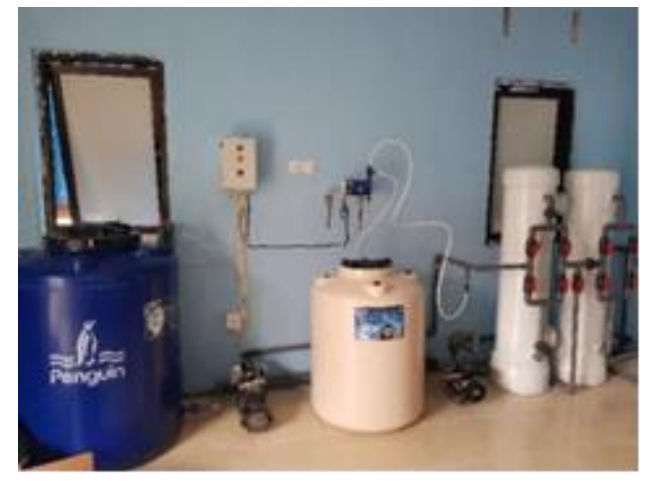

Gambar 12. Unit Pretreatment

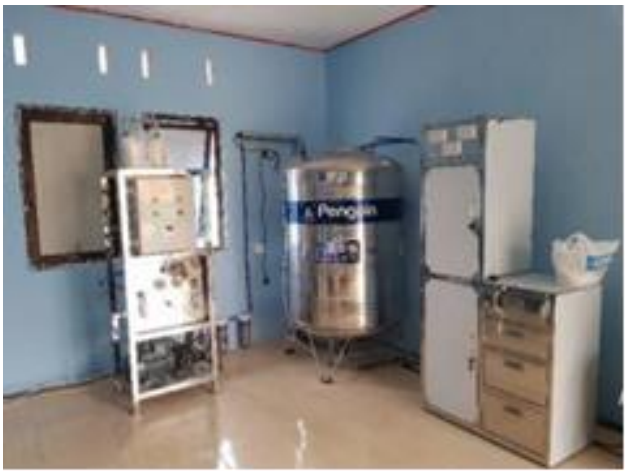

Gambar 13. Unit Reverse Osmosis

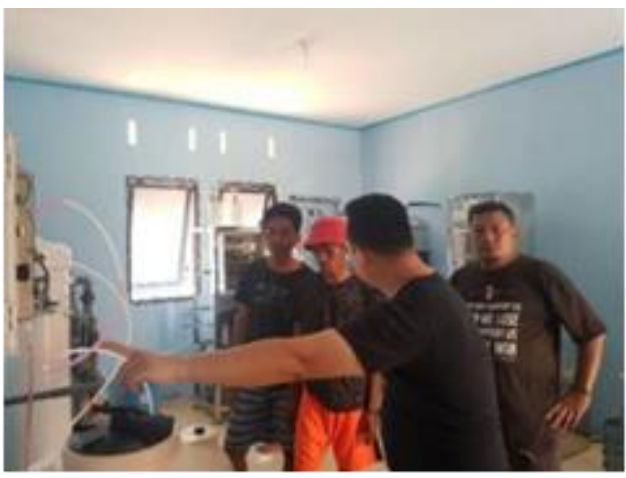

Gambar 14. Pelatihan Operator 
Tabel 7. Hasil Analisa Produk Olahan

\begin{tabular}{|c|c|c|c|c|}
\hline \multirow[b]{2}{*}{ No } & \multirow{2}{*}{ Parameter } & \multirow{2}{*}{ Satuan } & \multirow{2}{*}{$\begin{array}{c}\text { Baku } \\
\text { Mutu*) }\end{array}$} & Hasil \\
\hline & & & & Air Produk Arsinum \\
\hline 1 & $\mathrm{pH}$ & - & $6-9$ & 7,01 \\
\hline 2 & Kekeruhan & NTU & 5 & 1,81 \\
\hline 3 & TDS & $\mathrm{mg} / \mathrm{L}$ & 500 & 221 \\
\hline 4 & Temperatur & ${ }^{\circ} \mathrm{C}$ & $\begin{array}{c}\text { Air } \\
\text { Normal }\end{array}$ & 26 \\
\hline 5 & Besi (Fe)Terlarut & $\mathrm{mg} / \mathrm{L}$ & 0,3 & $<0,03$ \\
\hline 6 & $\begin{array}{c}\text { Mangan } \\
\text { (Mn)Terlarut }\end{array}$ & $\mathrm{mg} / \mathrm{L}$ & 0,4 & $<0,01$ \\
\hline 7 & Total Coliform & $\begin{array}{c}\mathrm{MPN} / 100 \\
\mathrm{~mL}\end{array}$ & 0 & 0 \\
\hline 8 & E Coli & - & 0 & Negatif \\
\hline
\end{tabular}

Sumber: Hasil analisa laboratorium PTL, 16 Desember 2019

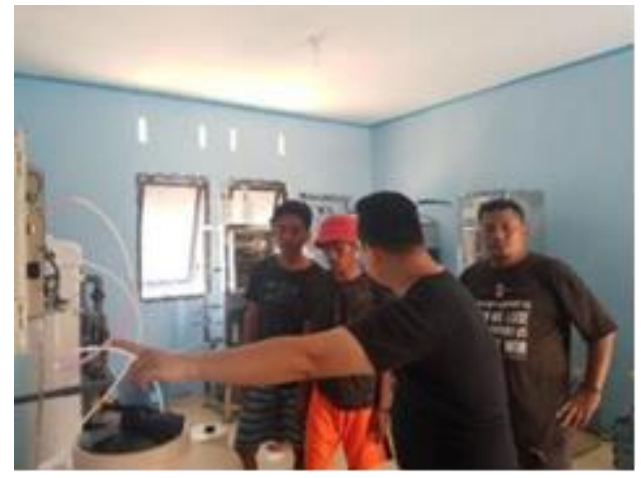

Gambar 15. Peresmian unit reverse osmosis oleh Gubernur Sulawesi

Selatan

\subsection{Perhitungan Biaya Energi}

Sumber daya yang digunakan unit reverse osmosis ini adalah genset dengan kapasitas 15 kva dengan bahan bakar bensin. Pemilihan bahan bakar bensin, karena bensin lebih mudah diperoleh di P. Barrang Caddi dibandingkan dengan bahan bakar lainnya. Adapun perhitungan biaya bahan bakar tersebut sebagai berikut.

Otto (gasoline) engine: 273- 227 $\mathrm{g} / \mathrm{kw} / \mathrm{hr}$, Nilai rata-rata $=250$ $\mathrm{g} / \mathrm{kw} / \mathrm{hr}$ (Baddaruddin, 2015)

Berat jenis suatu bahan bakar bergantung pada temperatur dan kandungannya, secara umum dapat diambil harga rata-rata dari Wikipedia sebagaimana di bawah ini.

- Bensin 0,745 kg/L

- Solar 0,832 kg/L

Dari segi perhitungan bahan bakar di genset adapun keterangannya sebagai berikut : 


$$
\begin{aligned}
& \mathrm{K}=250(\text { Faktor ketetapan } \\
& \text { konsumsi solar per kilowatt per } \\
& \text { jam) } \\
& \mathrm{P}=\text { Daya genset }(\mathrm{kva}=\text { Kilo Volt } \\
& \text { Ampere) } \mathrm{T}=\text { Waktu (jam) } \\
& \mathrm{S}=250 \times \mathrm{P} \times \mathrm{T}
\end{aligned}
$$

Biaya kebutuhan bahan bakar bensin perhari

$\begin{array}{ll}\text { Berat jenis bensin } & =0,745 \mathrm{~kg} / \mathrm{l} \\ \text { Daya genset } & =15 \mathrm{kva} \\ \text { Waktu }(\mathrm{t}) & =24 \mathrm{jam}\end{array}$

$$
\begin{aligned}
& S=250 \times P \times t \\
& S=250 \times 15 \times 24 \\
& S=93,750 \frac{g}{h} \\
& S=93.75 \mathrm{~kg} / \mathrm{h} \\
& L=\frac{93.75 \mathrm{~kg} / \mathrm{h}}{0.745 \mathrm{~kg} / 1}=125.8 \mathrm{~L} / \mathrm{h}
\end{aligned}
$$

Bila beroperasi selama 8 jam

$L=\left(\frac{93.75 \mathrm{~kg} / \mathrm{h}}{0.745 \mathrm{~kg} / 1}\right): 4=125.8 \frac{L}{h}: 4=31 L$

Volume tangki air siap minum adalah 1000 liter dalam pengoperasian, sehingga ditetapkan produksi air siap minum 8 liter

permenit untuk memenuhi tangka produk air siap minum maka di butuhkan waktu \pm 2 jam pengoperasian, maka bensin yang dibutuhkan adalah

$$
\begin{aligned}
& S=250 \times P \times t \\
& S=250 \times 15 \times 2 \\
& S=7500 \frac{g}{h}=7.5 \mathrm{~kg} / \mathrm{h}
\end{aligned}
$$

$$
L=\frac{7.5 \mathrm{~kg} / \mathrm{h}}{0.745 \mathrm{~kg} / 1}=10 \mathrm{~L}
$$

Harga bensin premium perliter Rp. $9.200,00$.

Biaya bahan bakar $=10 \mathrm{~L} \times R p 9.200,00$ Biaya bahan bakar $=R p 92.000,00$

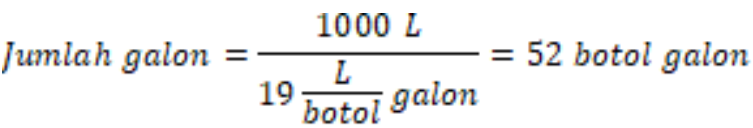

Bila per gallon di jual Rp. 5000 maka per 1000 liter menghasilkan Rp $260.000,00$ dan dalam sebulan bisa mendapat $R p 260.000 \times 30$ hari $=R p$ 7.800.000,00. Berdasarkan perhitungan tersebut maka dapat diketahui bahwa keuntungan dari penjualan bisa digunakan untuk menggaji operator dan kebutuhan penggantian sparepart bila diperlukan.

\section{KESIMPULAN}

Dari hasil evaluasi desain pengolahan air minum menggunakan membran reverse osmosis kapasitas $10 \mathrm{~m}^{3} /$ hari, maka dapat disimpulkan beberapa hal sebagai berikut.

- Pengolahan air berbasis masyarakat ini adalah untuk memenuhi kebutuhan air bersih / air minum untuk daerah - daerah yang sulit air bersih.

- Reverse osmosis adalah salah satu alternatif teknologi untuk mengatasi permasalahan air minum di pulau - pulau terpencil. 


\section{DAFTAR PUSTAKA}

Baddaruddin, Ferdi H. 2015. Perhitungan Optimasi Bahan Bakar Solar pada Pemakaian Generator Set Di BTS. Jurnal Teknologi Elektro. Universitas Mercu Buana: Vol 6 No. 2, Jakarta.

D. Ariyanti, Widiasa, I N. 2011. Aplikasi Teknologi Reverse Osmosis untuk Kemurnian Air Skala Rumah Tangga. Jurnal Teknik. 32(3) Tahun 2011, ISSN 0852-1697. Yogyakarta.

Herlambang A. 2016. Aplikasi Sistem Penyediaan Air Bersih Berbasis Masyarakat Di Pulau Pandangan, Kabupaten Pangkajene, Sulawesi Selatan. JAI Vol. 9 No. 1

Mulder, M. 1996. Basic Principles of Membrane Technology. Dordrecht: Kluwer Academic Publisher.

Purwono, Karbito. 2014. Pengolahan Air Sumur Gali Menggunakan Saringan Pasir Bertekanan (Presure Sand Filter) untuk Menurunkan Kadar Besi (Fe) dan Mangan (Mn). Jurnal Kesehatan, Vol 4, No.1. Lampung.

Safri, Burhanudin, dkk. 2006. Wisata Bahari Makassar (Marine Tourism of Makassar). Jakarta: Ara Sinergi Optima.

Said.I. N. 2010. Pengolahan Payau menjadi Air Minum dengan Teknologi Reverse Osmosis". Jakarta.

Widayat, Wahyu. 2007. Aplikasi
Teknologi Pengolahan Air Asin Desa Tarupa, Kecamatan Taka Bonerate, Kabupaten Selayar. Jurnal Air Indonesia. 03(1): 81 $-95$.

Widiasa, I N. dan Susanto, A.A. 2016. Tekno Ekonomi Sistem Membran Terintegrasi untuk Pengolahan Air Baku Campuran Air Payau dan Effluen STP. Prosiding Seminar Nasional Teknik Kimia "Kejuangan". ISSN 1693-439. Yogyakarta.

William, M.E. 2003. A Brief Review of Reverse osmosis Membrane Technology. EET Corporation and Williams Engineering Services Company. 